\title{
A magaslégköri repülő platformok és lehetséges alkalmazhatóságuk
}

A magaslégköri repülő platformokkal kapcsolatos tudományos gondolkodás már több évtizedes múltra tekint vissza. A gyakorlati megvalósításukhoz szükséges technológiák azonban csak az utóbbi időben váltak elérhetővé, így napjainkban egy fontos átmeneti időszakban dolgozunk: már léteznek példák a megvalósult repülőeszközökre, de még nincs kialakult üzemeltetési tapasztalatunk és megvalósult ökoszisztémánk.

A pszeudoműhold néven is ismert repülőeszközök nagyon jó lehetőségeket biztosítanak az űrrendszerek kiegészítésére vagy helyettesítésére, de a művelettervezőknek figyelembe kell vennük az eszközök korlátait, amelyek jelentősen eltérnek mind a légi-, mind az ürműveletek tervezése során megszokottól.

A tanulmány rövid áttekintést nyújt a magaslégköri repülő platformokról (HAPS - High-altitude platform systems) egy hipotetikus műveleti szcenárió alapján. A műveleti forgatókönyv szimulációja az AGI Systems Tool Kit szoftverrel készült [1].

\section{A MŰVELETI SZCENÁRIÓ BEMUTATÁSA}

2020 decemberének utolsó napjaiban a Magyar Honvédség magaslégköri repülőeszköze - az Agrárminisztérium tevékenységének támogatása érdekében - a Duna mentén hajtott végre távérzékelési feladatot multispektrális, nappali és éjszakai felvételek készítésére is alkalmas szenzorcsomagot szállítva. 2020. december 29-én egyezményes koordinált világidő ${ }^{1}$ (UTC - Universal Time Coordinated) szerint 11:20kor egy 6,2-6,4 magnitúdójú földrengés pattant ki a horvátországi Petrinya település térségében.

A természeti katasztrófa bekövetkeztét követően a kormányzati szereplők számára egyértelművé vált, hogy nyílt forrásokból szerzett adatok alapján - és azzal a proaktív feltételezéssel élve, hogy a földrengés okozta károk felmérésében szövetséges szomszédunk részére támogatást kell nyújtanunk -, a repülőeszköz irányítója a vezetői feladatszabásnak megfelelően a folyamatban lévő feladatot

ÖSSZEFOGLALÁS: A technológia fejlödése mára lehetővé tette, hogy a légköri repülés határait új magasságokba emeljük. A sztratoszférarepülö, magaslégköri, személyzet nélküli repülőeszközök szolgáltatásai már-már múholdszerüek, ezért kapták egyik közkeletű nevüket is: pszeudomüholdak Számos eltérést találunk azonban az ürrepülő müholdak és a magaslégköri repülő platformok, illetve a hosszú őriáratozási idejü, de alacsonyabb repülési pályán múködő, pilóta nélküli eszközök alkalmazhatósága és szolgáltatásai között. Ez a tanulmány egy valószerú múveleti szcenárió alapján bemutatja a sztratoszférarepülő pszeudomúholdakat és összehasonlítja azokat a megjelölt két másik elterjedt múvelettámogató platformmal.

KULCSSZAVAK: magaslégköri repülő platformok, HAPS, AGI Systems Tool Kit szoftver, Petrinya földrengés, RPAS, pszeudomúhold megszakította, és a legrövidebb úton a káresemény térségébe irányította azt. A magaslégköri repülő 11:28 időpontban az átrepülési irányra fordult, és sebességét $22 \mathrm{~m} / \mathrm{s}-\mathrm{ra}$ növelte.

Eközben a szükséges engedélyek megszerzése érdekében megkezdődött a szakmai és politikai egyeztetés, valamint egy telepíthető adatletöltő állomás előkészítése légi szállításra. A horvát kormány a felajánlást elfogadta, a berepülést engedélyezte, illetve engedélyezte az adatletöltő állomás telepítését a Franjo Tudman Nemzetközi Repülőtéren, ahová azt légi szállítással haladéktalanul útba is indították.

A magaslégköri repülőeszköz 14:41 UTC-kor érkezett meg a Sisak közelében kijelölt sebességszabályozási ponthoz, ahol sebességét a távérzékeléshez megfelelő és energiatakarékos értékre, $18 \mathrm{~m} / \mathrm{s}$-ra csökkentette. Az átrepülés ideje alatt megtörtént a letöltő állomás kirakodása és üzembe helyezése, valamint az őrjáratozási útvonal kidolgozása az előzetes kárjelentések és hírigények alapján. Kritikus jelentőséggel bírt az epicentrum környékének felmérése, a szlovéniai Krsko atomerőmű megfigyelése, illetve a távolabbi, kárt szenvedett települések feltérképezése. Mivel a földrengés szlovéniai és bosznia-hercegovinai területeken is kárt okozott, a magyar hatóságok ezektől az országoktól is beszerezték a repülőeszköz müködtetéséhez szükséges engedélyeket. Az 1. ábrán a szlovén települések kék, a horvát települések piros, a bosznia-hercegovinai települések pedig sárga színnel szerepelnek².

A távérzékelő szenzor elméleti hatókörébe már 14:02 UTC-kor belépett Petrinya, 14:58 UTC-kor pedig már közel függőleges irányból is megkezdődhetett a felvételek készítése (2. ábra). Ekkor még a kamera nappali üzemmódban működött. 15:14 UTC-kor besötétedett, ezután az éjszakai kamera vette át a feladatot. Az irányítás továbbra is műholdas adatkapcsolaton keresztül történt, de a felvételek letöltése már a Zágráb közelében telepített állomáson, közvetlen rádiókapcsolattal valósult meg.

15:45 UTC-kor megkezdődött az atomerőmű légi felvételezése ferdén előre néző szenzorral, függőleges irányból

ABSTRACT: The advancement of technology enabled us to lift the boundaries of atmospheric flight again. Stratospheric remotely piloted aerial systems can provide services comparable to outer space satellites, that is why they are often called pseudosatellites. At tha same time, we can find significant differences between the applications and services of space satellites, high-altitude platforms, and the long endurance, but lower altitude remotely piloted aircraft. This article introduces the sptratospheric pseudosatellites and compares them to the other two aforementioned mission support platforms, via a realistic operational scenario.

KEY WORDS: High-altitude platform systems, HAPS, AGI Systems Tool Kit szoftver, Petrinya earthquake, RPAS, pseudosatellite

\footnotetext{
Alezredes, MH Modernizációs Intézet, Kutatás-fejlesztési lgazgatóság Műhold Operációs Képességek Osztály osztályvezető. ORCID: 0000-0001-9768-5357.
} 


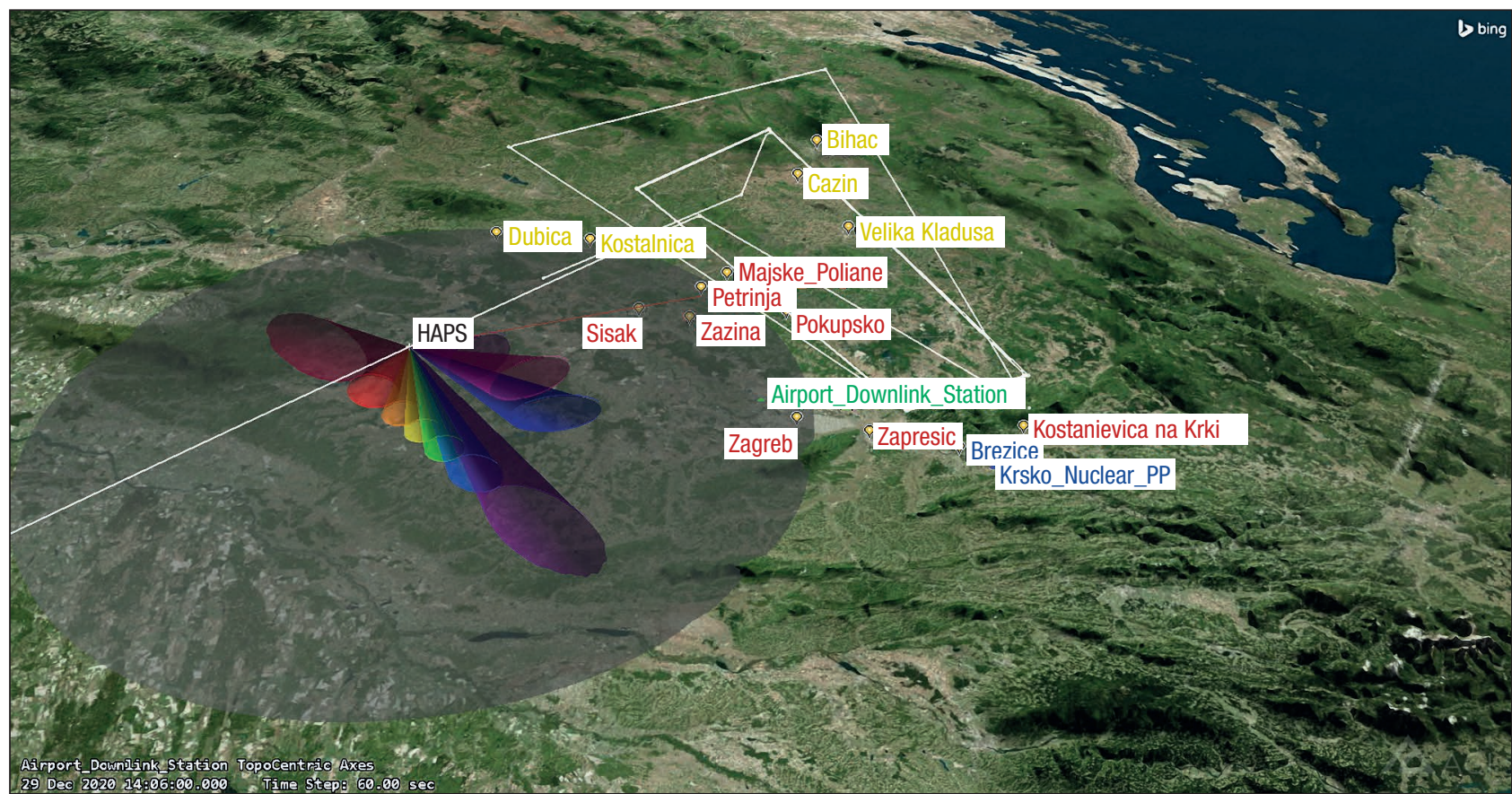

1. ábra. A múveleti terület áttekintése az őrjáratozás útvonalával, a földrengésben érintett településekkel és a HAPS elméleti belátott területén belül definiált (példaként szolgáló) szenzor kitekintési kúpokkal (A szerző szerkesztése)

pedig 16:13 UTC-kor (4. ábra). Ezt követően a repülőeszköz bejárta a kárt szenvedett területeket az epicentrumtól délre, majd visszatért Petrinya fölé, és ezután az epicentrum környéke és az atomerőmű által meghatározott útvonalon repült az éjszaka során (3. ábra), figyelve az utórengésekre utaló jeleket, illetve folyamatosan adatokat szolgáltatott a kárelhárításhoz.

Figyelemmel a rendszeresen jelentkező, önmagukban is jelentős energiájú, 3,3-4,9 magnitúdójú utórengésekre, a magaslégköri repülőeszköz január 10-ig folytatta az őrjáratozást 20 km magasságban, majd viszszarepült Magyarországra.

\section{A SZCENÁRIÓ HÁTTERE, A MAGASLÉGKÖRI REPÜLÖESZKÖZÖK BEMUTATÁSA}

A fenti történet jelentős részben a képzelet szüleménye, azonban fontos illusztráció ahhoz, hogy bevezesse a tanulmány témáját: a magaslégköri repülő platformokat. A horvátországi földrengés természetesen megtörtént, és 7 halálos áldozatot követelt. A szlovén atomerőművet vészeljárással leállították, kárt nem szenvedett, mert földrengésállósága jelentősen magasabb szintű volt, mint a ténylegesen bekö-

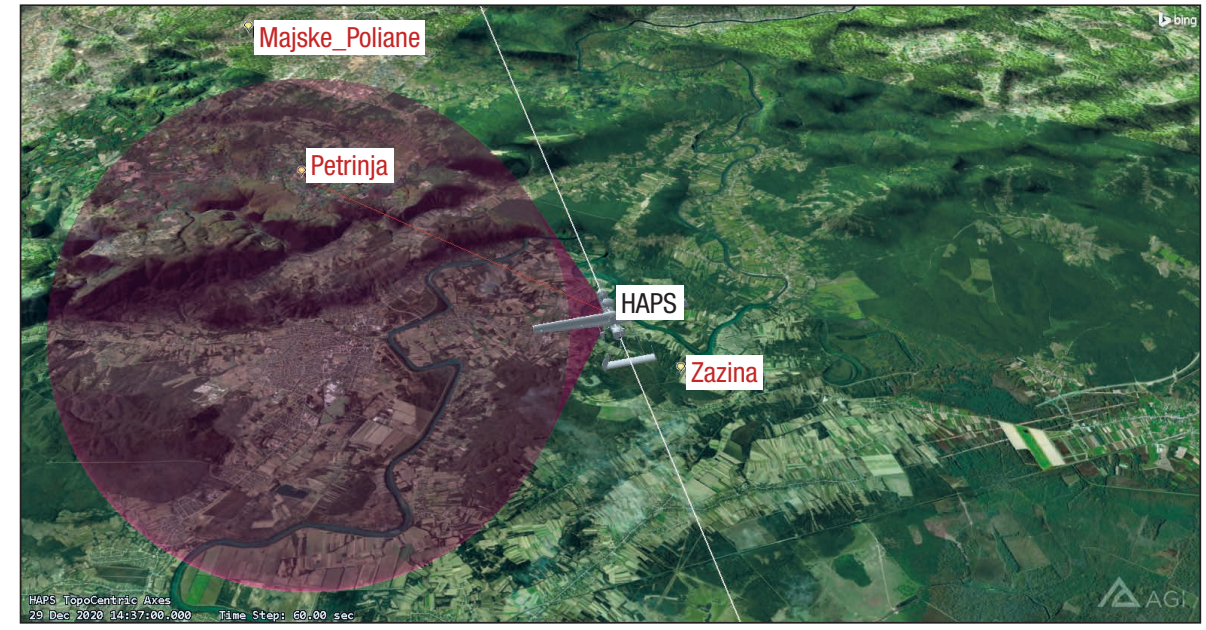

2. ábra. A HAPS szenzora Petrinya települést deríti fel (A szerző szerkesztése)

3. ábra. A HAPS szenzora az esti szürkületben az atomerőmúvet vizsgálja (A szerző szerkesztése)

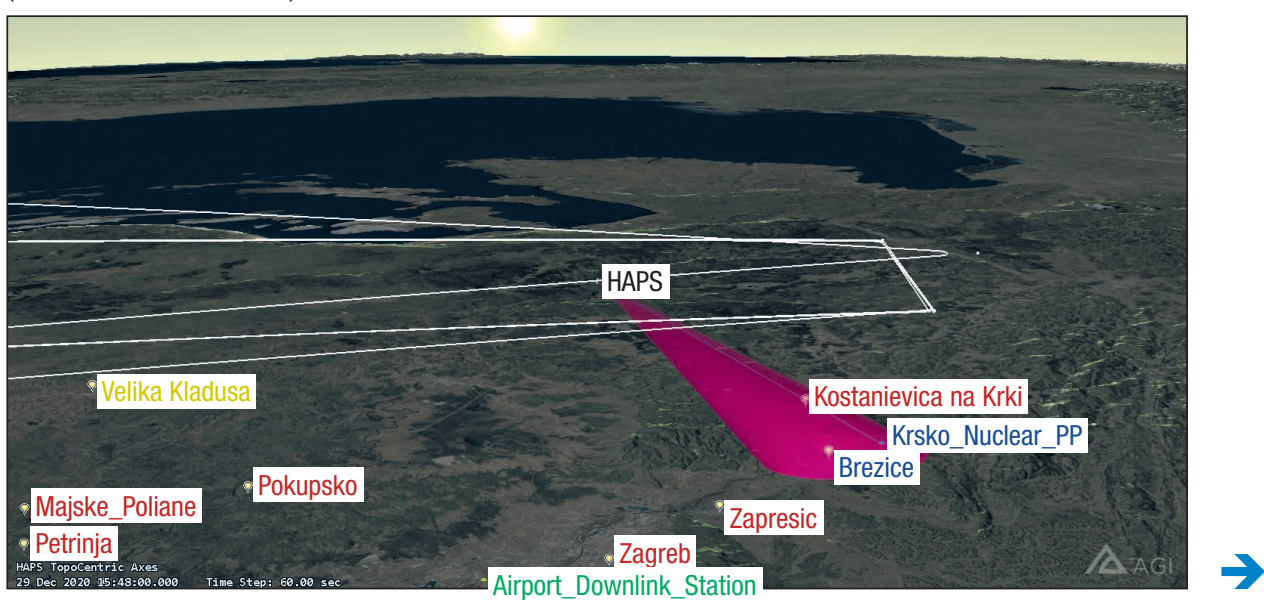




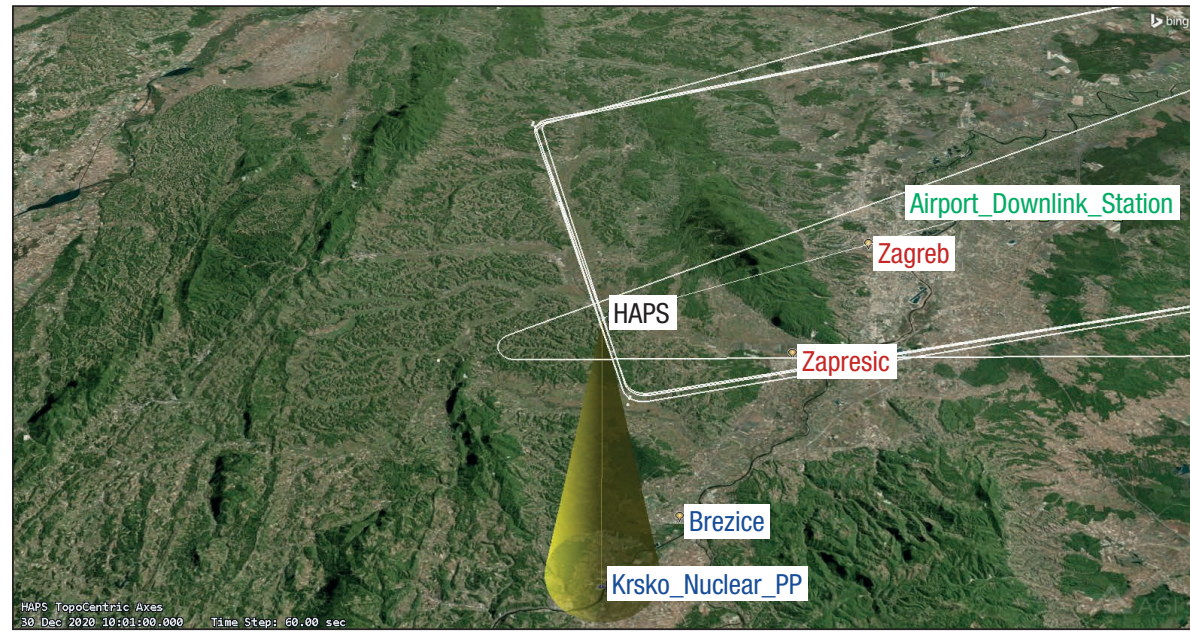

4. ábra. A HAPS szenzora nappali fényben, közel függőlegesen kitekintve deríti fel az atomerőművet, az adatokat pedig a repülötéren telepített letöltőállomásra továbbítja (A szerző szerkesztése)

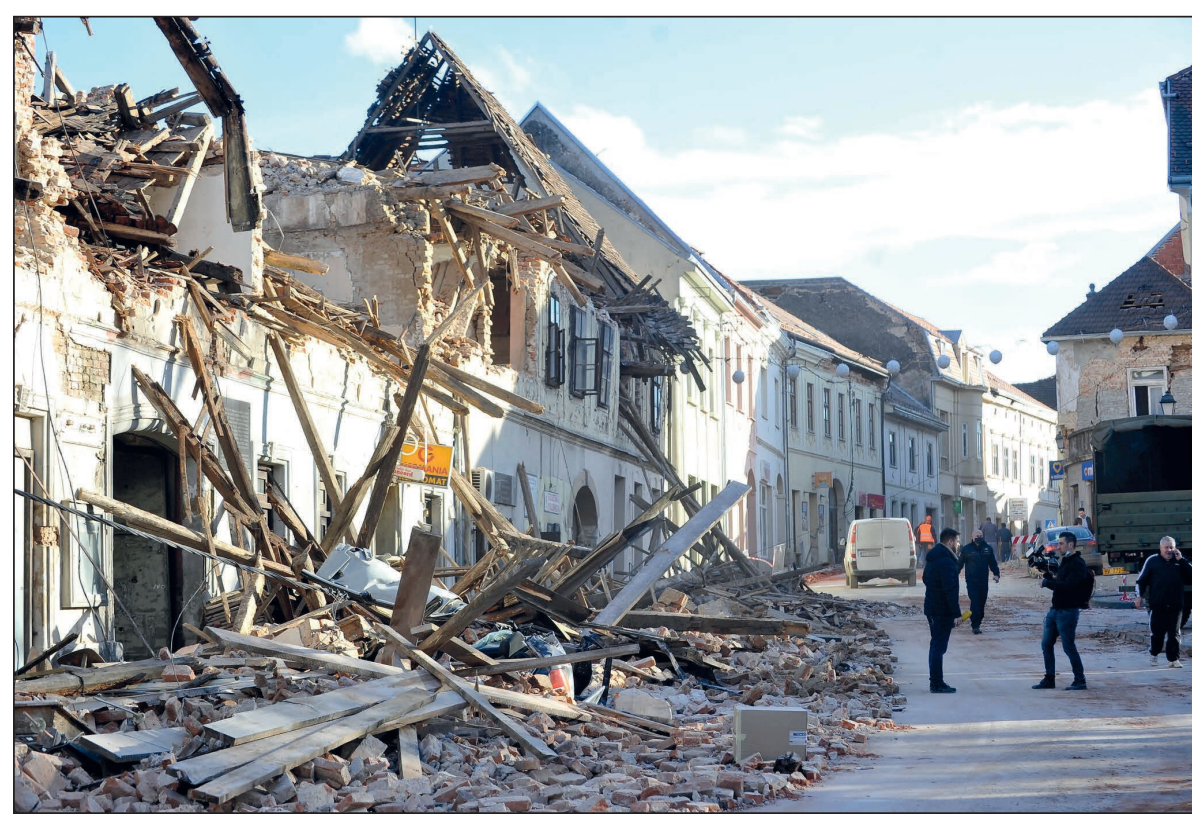

5. ábra. A petrinyai földrengés pusztítása (Forrás: [2] AP)

vetkezett rengés. Magyarország az elsők között ajánlotta fel segítségét szomszédjának, egyrészt az azonnali kárenyhítésben (fektetési anyagok és élelmiszer), másrészt a hosszabb időtávú újjáépítésben. A kitalált történetben leírtakkal ellentétben, a Magyar Honvédség jelenleg még nem rendelkezik sztratoszférarepülő légi járművekkel.

A magaslégköri repülőeszközök (magaslégköri platformok, sztratoszférarepülő légijárművek, pszeudoműholdak) kutatása több évtizedes múltra tekint vissza, a gyakorlati megvalósításukat a technika fejlődése azonban csak napjainkban tette lehetővé.

A pszeudoműholdak légköri, aerodinamikus vagy aerostatikus repülőeszközök. Ebben a magasságban a légkör már igen ritka, de még lehetséges felhajtóerő termelése korszerü, erős és könnyű anyagokból épített járművekkel. A légkör napfényelnyelő hatása itt kisebb, így a napelemes energiatermelés (adott napelemfelületre vetítve) hatékonyabb, mint a földfelszínen, és ez az energia megfelelő akkumulátorokban tárolható az éjszakai repülés idejére is. A légkör a sztratoszférában, a jetstream (magaslégköri fu- tóáramlás) felett igen nyugodt az alacsonyabb réteghez (a troposzférához) képest, így miután a repülőeszköz felemelkedett a hozzávetőlegesen $20 \mathrm{~km}$ feletti üzemi repülési magasságba, alacsony sebességgel is képes hatékony manőverezésre. A magaslégköri repülő platformok a gyakorlatban minden esetben személyzet nélküli, autonóm, illetve távirányított repülőeszközök [3].

\section{A MAGASLÉGKÖRI REPÜLŐESZKÖZÖK MÜSZAKI JELLEMZŐI}

A pszeudoműholdak a repüléshez szükséges felhajtóerő termelése és a manőverezőképesség szempontjából alapvetően három módon valósíthatók meg, és ma mindháromra láthatunk létező, vagy tervezett példákat.

$A z$ első lehetőség egy aerodinamikus repülőeszköz, egy levegőnél nehezebb merevszárnyú RPAS - Remotely Piloted Aircraft System (távirányított légijármürendszer), amely a sárkányszerkezetre helyezett napelemekke termeli az energiát az elektromos hajtómotorok és a fedélzeti eszközök számára. (6. ábra) A felhajtóerőt és a manőverezést egyaránt a motorok vonóereje biztosítja. Nappal a napelemek töltik az akkumulátorokat és hajtják a hajtómotorokat, éjszaka pedig a repülőeszköz az akkumulátorokban tárolt energiát használja fel. A repülés idejét csak a hajtómotor-karbantartások közötti üzemidő és az energetikai rendszer degradációja korlátozza.

A második lehetőség egy aerostatikus repülőeszköz, puha vagy félmerev testű léghajó, amely napelemekkel táplált elektromotoros meghajtással rendelkezik. Ennél a változatnál a felhajtóerőt a levegőnél könnyebb léghajótest termeli, a motorok csak a vízszintes síkban történő manőverezéshez szolgáltatnak tolóerőt. A nagy léghajótest miatt azonban a közegellenállás hatása is nagyobb, viszont egyidejűleg nagyobb felület áll rendelkezésre a napelemek számára (amelyek ugyanakkor növelik a repülőeszköz tömegét). (7. ábra) A felhajtóerőt termelő gáz a hélium (a hidrogén az alacsonyabb sűrűsége és a kisebb szivárgási képessége miatt ugyan alkalmasabb lenne, de rendkívül tűzveszélyes). A hélium, kis molekulamérete miatt folyamatosan szivárog, a léghajótest „leereszt”, amely szintén korlátozza a bevetések idejét. A hélium emellett nem tekinthető megújuló erőforrásnak, a Földön csak kis mennyiségben fordul elö, és igen drága.

A harmadik műszaki megoldás szintén aerostatikus, héliummal töltött gázballon, amely saját meghajtással nem rendelkezik. (8. ábra) A felhajtóerő változtatásával lehetsé- 


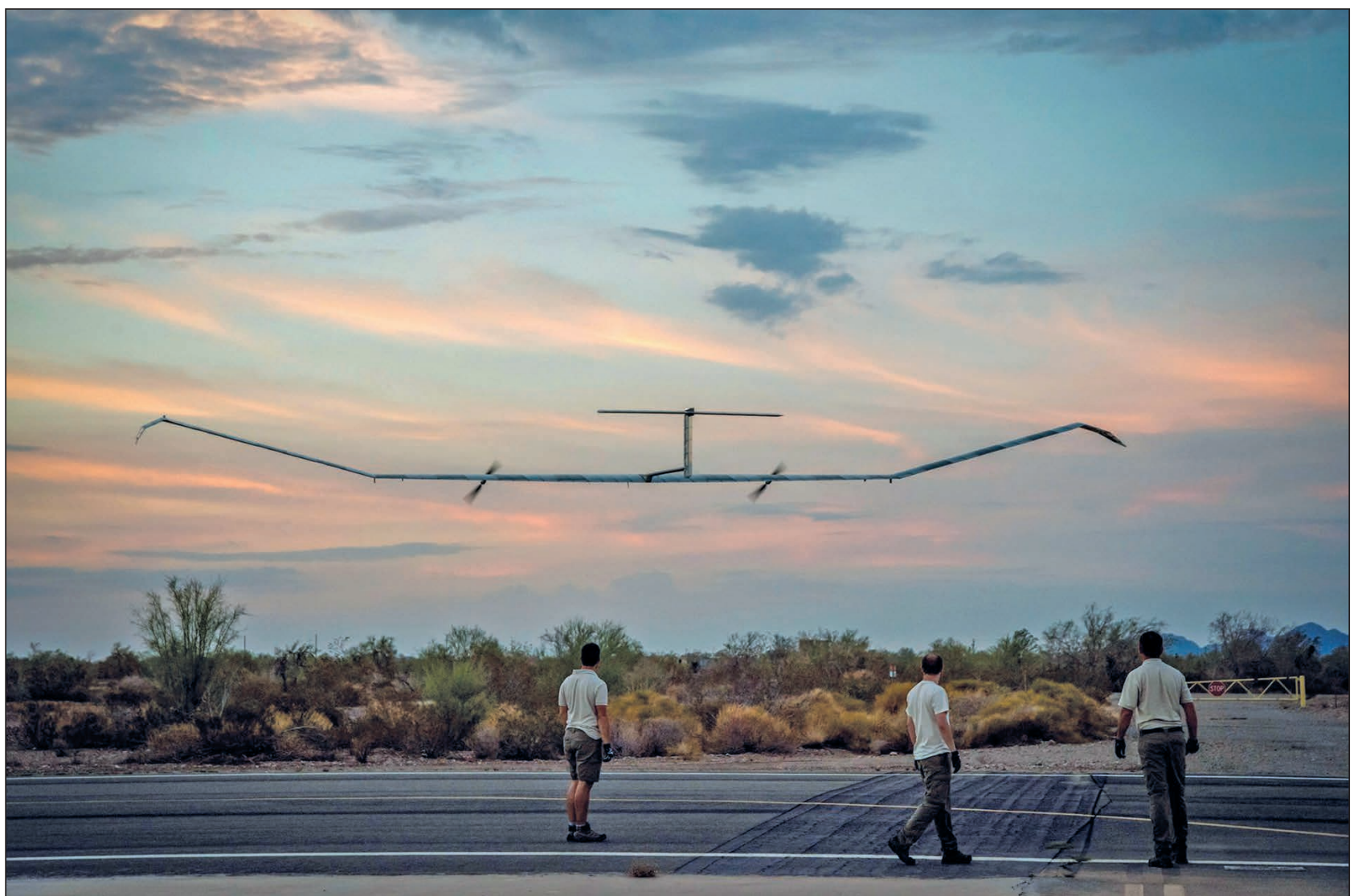

6. ábra. A sztratoszférában repülő Airbus Zephyr S RPAS közvetlenül felszállás után (Forrás: [4] Airbus)

ges a különböző irányba fújó szelek szintjére manőverezni függőleges irányban, vízszintesen azonban a szelek sodorják a ballont. A pillanatnyi és az előre jelzett magaslégköri szélviszonyok alapján 3 dimenzióban tervezhető a ballon repülési útvonala. Egy adott pont felett (azaz a pont környezetében) való tartózkodás (stationkeeping) során a ballon folyamatosan változtatja a repülési magasságát azért, hogy rövid idejű sodródás után a szembe fújó légáramlás az ellenkező irányba sodorja, majd vissza, és így tovább. Ezáltal a ballon soha nem hagyja el a kijelölt alkalmazási terület környezetét. A függőleges manőverezés az emelőgáz által termelt felhajtóerő és a repülőeszköz tömege közötti viszony változtatásával történik. Ez megvalósítható a gáz melegítésével-hűtésével (a meleg gáz kitágul és

7. ábra. Thales Alenia Stratosbus magaslégköri léghajó (Forrás: [5] Thales)

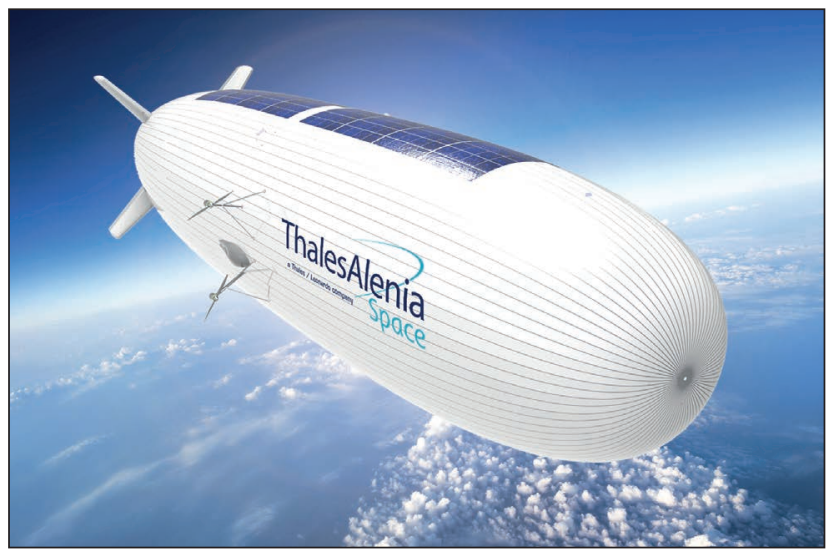

8. ábra. 4G mobiltelefon-átjátszót szállító ballon felszállás előtti ellenőrzése (Forrás: [6] ESDPA)

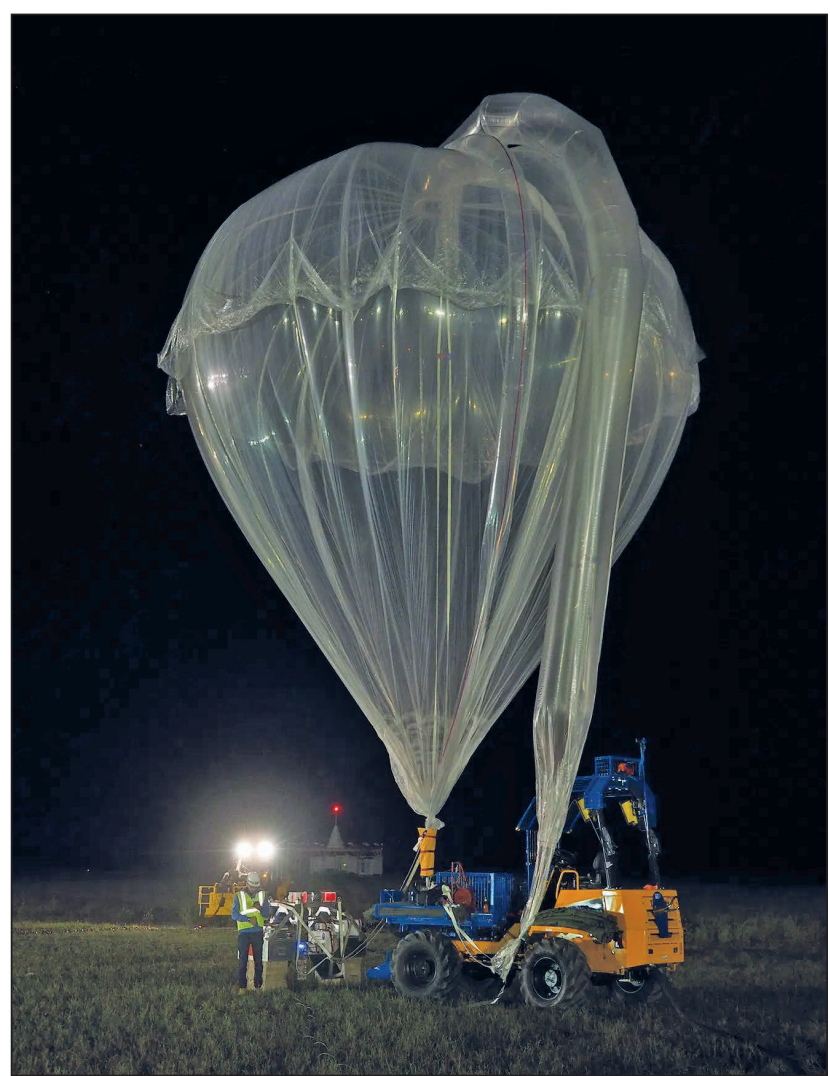


nő a felhajtóerő), tárolótartályból a ballonba engedésévelkiszivattyúzásával (a ballon felfújásával a felhajtóerő nő), illetve levegőzsákok felfújásával-ürítésével (a hélium olyan alacsony sürüségü, hogy ahhoz képest a levegő is ballasztsúlyként használható). A ballon üzemidejét elsősorban az emelőgáz folyamatos csökkenése korlátozza. Amikor a gáz fogyása miatt a repülés már nem fenntartható, akkor a ballon felvágásával a héliumot kiengedik, így az közel függőlegesen zuhan le egy arra engedélyezett, koordinált légtérben. Emiatt ez a megoldás még inkább gázpazarló, hiszen a repülést követően a gáz visszanyerésére semmilyen lehetőség nincs (ellentétben a léghajóval, ahol a kontrollált leszállás után a gáz kiszivattyúzható, amennyiben az eszköz nem indul rövid időn belül újabb repülésre).

Bárhogyan is valósuljon meg a repülőeszköz, a repülési profil gyakorlatilag azonos: az indítóhelyről a lehető legkevesebb vízszintes síkú mozgással el kell érni a sztratoszférát. Figyelembe kell venni, hogy még a leginkább manőverezőképes pszeudoműholdak (a merevszárnyú repülők) sem tudják leküzdeni a magaslégköri futóáramlást (a jetstreamet), így óhatatlanul elsodródnak, ezt a jelenséget a légtér biztosításánál figyelembe kell venni. A jetstream egyidejüleg azonban felhasználható arra is, hogy amennyiben a múveleti terület az indítási helytől távol van, akkor a repülőeszköz a jetstream magasságában maradva abban „utazik”, sodródik, így nagyobb sebességgel tud haladni és energiát takarít meg. Csak a célkörzet közelébe érve emelkedik a futóáramlás fölé, és kezdi meg az önálló manőverezést a hajtómúvei vagy a nyugodtabb légrétegek szeleinek felhasználásával [7].

Hogy milyen módon zajlik az önálló manőverező repülés, az a műveleti feladattól, és a környezeti hatásoktól függ. A repülés végrehajtható egy pont közelében maradva, egy meghatározott terület felett őrjáratozva, vagy útvonalat repülve. Nappal a repülőeszköz általában emelkedik, így helyzeti energiát halmoz fel, éjszaka pedig süllyed. Ez lehetővé teszi, hogy a merevszárnyú UAV - Unmanned Aerial Vehicle, (személyzet nélküli légi jármű) takarékoskodjon az akkumulátorokban tárolt energiával (a helyzeti energiát használja fel a sikláshoz, mint a vitorlázórepülők), a felhajtóerőt emelő gázzal biztosító kialakítások pedig a gáz lehülése miatt süllyednek. A példa szcenárióban a nappali-éjszakai magasságváltozás nem szerepelt.

$\mathrm{Az}$ adott műveleti feladat befejezése után a sztratoszférarepülő platform - a hátralévő repülési idejétől és a feladattervtől függően - saját manőverezőképességét kihasználva indulhat új feladatra (ezt ábrázolta a példaszcenárió), vagy pedig a jetstreamben sodródva juthat el az új múveleti területhez. Ha nincs további feladata, akkor a felszáló manőverhez hasonlóan, visszarepülve a leszállóhelyhez, ott egy erre a célra engedélyezett légtérben leereszkedik és leszáll (a ballon pedig végrehajtja az emelőgáz kiengedését és lezuhan).

\section{A MAGASLÉGKÖRI REPÜLŐ PLATFORMOK GYAKORLATI ALKALMAZHATÓSÁGA}

A pszeudomúholdak gyakorlati elterjedése napjainkban zajlik. Emiatt a tényleges üzemeltetési tapasztalatok még korlátozottak. A platformok biztosította képességek alapján azonban azt mondhatjuk, hogy átmenetet képeznek mind szolgáltatásaikban, mind a műveletek tervezésében és végrehaitásában a sűrű légköri, hosszú őrjáratozási idejű (High Altitude, Long Endurance - HALE), személyzet nélkül repülő repülőeszközök (mint például az RQ-4 Global Hawk és változatai, RQ-3 DarkStar, Bayraktar Akinci, WZ-7 Soar Dragon) és az űreszközök között.
A sűrü légköri repülőeszközök őrjáratozási távolsága és ideje kisebb, mint a sztratoszférarepülő platformoké, azonban teheremelő képességük és repülési sebességük nagyobb. Elméleti lefedettségi területük globálisnak tekinthető abban az értelemben, hogy átrepülés vagy átszállítás után, megfelelő bázisrepülőtérről üzemelve bárhol képesek végrehajtani a feladataikat, az irányítás, valamint a felderítési adatok átvitele pedig mủholdas távközlési rendszeren keresztül biztosítható. Előnyük, hogy gázturbinás sugárhajtómű biztosítja a meghajtást, generátor biztosítja a fedélzeti áramellátást, így függetlenek a napsugárzástól, nincs különbség a nappali és az éjszakai repülési profil között. A nagy teheremelő képesség és a jelentős rendelkezésre álló elektromos energia nagy méretű, nagy tömegű és energiaigényes hasznos terhek szállítását biztosítja, nem jelent problémát többek között aktív távérzékelő rendszerek vagy radarberendezések szállítása sem.

A nagy méret és tömeg azonban megkönnyíti a repülöeszköz észlelését, az alacsonyabb repülési magasság miatt a belátott terület kisebb, ezért közelebb kell repülni a célterülethez, és így könnyebb a légvédelmi fegyverekkel történő megsemmisítésük is. A rövidebb őrjáratozási idő megnehezíti a folyamatos megfigyelést, több repülőeszközt kell rotálni az őrjáratozási területen a megszakítás nélküli műveletvégrehajtás érdekében. Jelentősen nő az üzemeltetés anyagi- és humán erőforrásigénye, akiket a műveleti területen (annak közelében) kialakított előretolt bázison kell telepíteni, így megnő az ő veszélyeztetettségük is. Az őrjáratozási légtérbe történő kirepülés és az onnan való visszatérés időszükséglete azonos nagyságrendű a hasznos műveletvégrehajtási idővel, amely - folyamatos megfigyelés esetén - még jobban megnöveli a müvelet repülőeszköz-igényét.

Példaként megemlítjük, hogy a WZ-7 Soar Dragon névleges repülési ideje 10 óra, maximális repülési sebessége $750 \mathrm{~km} / \mathrm{h}$. $1500 \mathrm{~km}$ távolságban lévő célpont esetében hozzávetőlegesen 2 óra szükséges a kirepülésre, 2 óra a visszarepülésre (a felszálló és leszálló manőverek miatt ez a gyakorlatban némiképp több), így mindössze 6 óra marad a hasznos működésre. 24 óra alatt 4 felszállást kell végrehajtania a folyamatos megfigyeléshez. [8]

A Bayraktar Akinci 24 órát képes a levegőben maradni, de maximális repülési sebessége csak $360 \mathrm{~km} / \mathrm{h}$. Hasonló műveleti helyzetben az 1500 km-es kirepüléshez több mint 4 óra szükséges, a visszatéréshez ugyanennyi, a hasznos őrjáratozási idő így 16 óra - de az Akinci repülési magassága csak 2/3-a a Soar Dragonnak [9].

A kategória egyértelműen legmagasabb képességű eszköze az RQ-4B Block 40 Global Hawk, amely névlegesen harminc órát meghaladó őrjáratozási idővel rendelkezik [10].

A 9. és 10. ábrán összehasonlítható egy tipikus pszeudomủhold (20 km magasságban repülve), egy Global Hawk (vagy akár Soar Dragon, $18 \mathrm{~km}$ magasságban repülve) és egy Akinci (12 km magasságban repülve) elméleti belátott területe, 75 fokos félnyílásszögű kúpot használva. Fontos kiemelni, hogy a HAPS $20 \mathrm{~km}$-es repülési magassága a gyakorlati minimum, míg a másik két repülőeszköz a gyakorlati maximális repülési magasságán üzemel.

Az űreszközöket jelen összehasonlításunk érdekében két csoportra oszthatjuk. Az elsőbe tartoznak az alacsony Föld körüli pályán keringő műholdak. Ezek legnagyobbrészt a légköri fékezés hatástartománya felett, de a belső Van Allen sugárzási öv ${ }^{3}$ alatt, hozzávetőlegesen 250 és 1300 km közötti magasságtartományban keringenek. Az itt keringő műholdak a földfelszínhez képest relatív elmozdulnak, vagyis egy adott pontból nézve felkelnek a horizont fölé, áthaladnak az égbolton, majd lenyugszanak. Az átha- 


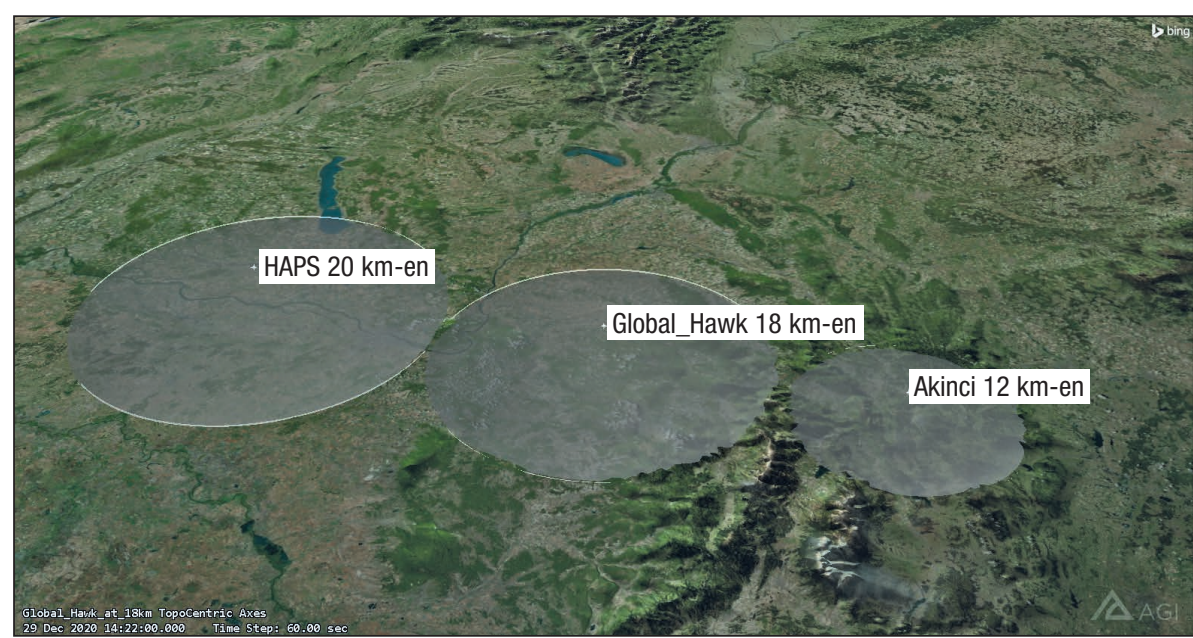

9. ábra. HAPS és más HALE RPAS repülőeszközök által belátott terület, közel felülnézetből (A szerző szerkesztése)

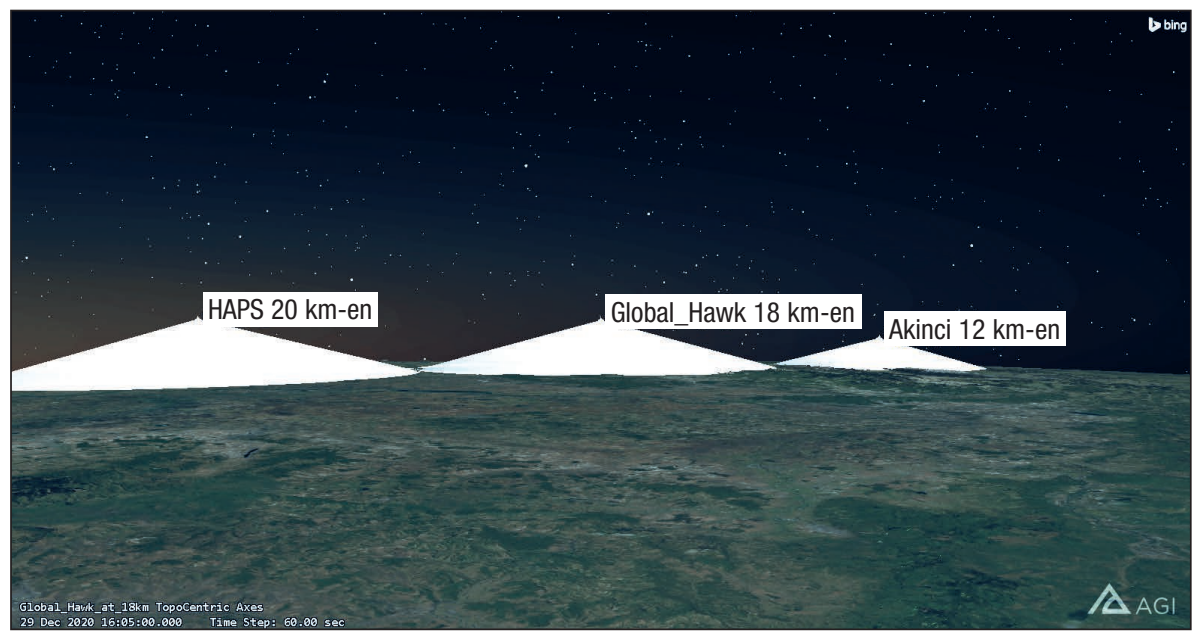

10. ábra. A belátott kúpok oldalnézetből (A szerző szerkesztése)

ladás ideje percekben mérhető, vagyis egy adott célpontot csak igen rövid ideig tud egy mühold megfigyelni. Azonban a műhold bejárja, így idővel belátja az egész földfelszínt (megfelelően megválasztott röppályaparaméterek esetén), és bizonyos idő múlva visszatér az említett pont fölé is, így egy adott terület megfigyelése periodikusan biztosított, a közbeeső időben pedig más területek is felderíthetők. Az alacsony pályamagasság igen részletgazdag képek készítését teszi lehetővé, akár passzív elektrooptikai szenzorokkal, akár radarral, ezért ezeket az űreszközöket tipikusan távérzékelési célokra hasznosítják. Távközlési feladatokra általában (bizonyos különleges szolgáltatásokat kivéve) akkor alkalmasak, ha nagyszámú müholdat tartalmazó konstellációkat építenek ki, és a kívánt szolgáltatási terület minden pontján biztosított, hogy mielőtt a földi állomás összeköttetése megszakadna a lenyugvóban lévő műholddal, már felkeljen egy másik műhold, amely át tudja venni az összeköttetést. Ugyanez a rendszerarchitektúra egyébként a folyamatos távérzékelő megfigyelést is biztosítani képes, de nagyon erőforrásigényes és a rendszer üzemeltetése is bonyolult.

$\mathrm{Az}$ alacsony Föld körüli pályán keringő müholdakhoz képest a magaslégköri repülő platformok előnye az, hogy ha az egy adott feladat során a megfigyelni kívánt terület jól behatárolható, akkor az oda kirepített pszeudomúhold folyamatos, perzisztens szolgáltatást tud nyújtani heteken, hónapokon keresztül. Igaz, eközben nem képes más területeket megfigyelni, de azt az egy adott területet állandóan, kiesés nélkül. Amennyiben a megfigyelési feladat rövidebb, mint a HAPS működési ideje, akkor a feladat végrehajtása után az eszköz új műveleti területre átreptethető [11].

A következő megvizsgálandó űreszköz-kategóriába a geostacionárius pályán keringő műholdak tartoznak. Az Egyenlítő síkjában, a földfelszín felett hozzávetőlegesen 36000 km magasságban keringő mühold keringési ideje megegyezik a Föld tengely körüli forgásának idejével, így a műhold a Föld forgásával szinkronban kering, és északdéli irányban sem mozdul el (a szolgáltatási rendszer által meghatározott ésszerű korlátokon belül). Emiatt a belátott terület állandó, a műhold a szolgáltatási területről folyamatosan látszik, méghozzá állandó kitekintési irányban. Emiatt ezek a műholdak igen kedvezőek távközlési szolgáltatások nyújtására, illetve kis felbontású képalkotó (például meteorológiai távérzékelési) feladatokra. A geostacionárius pályáról hozzávetőlegesen a földfelszín 44\%-a látható be (a mühold alatti félgömb peremterületei nem látszanak, ez elsősorban a sarkvidéki területeken okoz problémát, mert a keleti és nyugati peremet más pályapozícióból, másik műholddal le lehet fedni). A belátott területen belül a geostacionárius műholdak perzisztens és magas minőségű szolgáltatást tudnak nyújtani.

Napjainkban azonban ilyen űreszközök gyártására és pályára állítására nagyon kevés állam, vagy vállalkozás képes. Az Amerikai Egyesült Államok, Oroszország, Franciaország, Kína, India, Japán állami és kereskedelmi szervezetei rendelkeznek megfelelő rakétával a pályára állításhoz. A felsoroltakon kívül nem sokkal több ország gyártói képesek elkészíteni a műholdat (például Izrael, Nagy-Britannia). Egy ilyen mủhold tervezési élettartama 12-15 év, a valós üzemeltetési tapasztalat azt mutatja, hogy ezt néhány évvel túllépik, hacsak valami váratlan meghibásodás nem történik. De a tervezés, gyártás ideje is hozzávetőlegesen 3-5 év, így azzal kell számolnunk, hogy a műhold müszaki követelményeinek összeállításakor 20 évre előre kell tervezni.

A műhold és a földi állomás közötti igen nagy, hozzávetőlegesen $40000 \mathrm{~km}$ távolság azt eredményezi, hogy a jelterjedési idő jelentősen nagyobb, mint amit a földi hálózatokban megszoktunk. Ez bizonyos informatikai hálózati protokollok működését lerontja, illetve beszédkapcsolat esetén - amíg hozzá nem szoknak - a felhasználókat is zavarja.

A pszeudoműhold természetesen nem képes ekkora földrajzi területet egyszerre lefedni, de amennyiben a for- 
galom áramlási iránya jellemzően a lefedettségi területen belül tartózkodó állomások között található, akkor megfelelő szolgáltatásokat képes nyújtani. Ebben az esetben a geostacionárius távközlési műhold, a maga több ezer kilométeres nagyságrendű potenciális áthidalási távolságával, kizárólag ezeket a nagy távolságú kapcsolatokat biztosítja, míg a HAPS a lefedettségi területen (potenciálisan a harctevékenység, hadművelet vagy más katonai tevékenység területén) belül zajló forgalmazás nem terheli a müholdat.

További eltérés, és a támogatható műveletek portfólióját tekintve szignifikáns előny, hogy a HAPS szervizelhető, vagyis a néhány hetes-hónapos műveleti feladat végrehajtása után leszáll, és ekkor a hordozott hasznos teher cserélhető. A cserét motiválhatja a hasznosteher-technológia fejlődése, vagyis ugyanolyan szolgáltatási színvonal érdekében kisebb, könnyebb, kevesebb energiát igénylő műszaki megoldás alkalmazása (vagy azonos méret, tömeg, energiaigény mellett magasabb szolgáltatási színvonalat biztosító megoldás beépítése); illetve a megváltozó műveleti, alkalmazói igényhez történő alkalmazkodás.

\section{Összegzés}

A tanulmány egy elképzelt, de releváns művelet alapján, áttekintette a magaslégköri repülő platformok megvalósítási lehetőségeit és lehetséges alkalmazásukat, összehasonlítva a nagy repülési magasságú és hosszú őrjáratozási idejű személyzet nélküli repülőeszközökkel és a műholdakkal. Jól látható, hogy ez az új, napjainkban megvalósuló technológia jó kiegészítője mindkettőnek.

A több hétre, hónapra kiterjedő, és egy jól meghatározott földrajzi területet folyamatosan lefedő őrjáratozás képessége jellemzi a magaslégköri repülő platformokat, ami eltér mind az ürrepülő müholdaktól (hiszen egy területen perzisztens jelenlétet biztosít), mind a nagy repülési magasságú RPAS-októl (hiszen azokhoz képest jelentősen hosszabb ideig biztosítja a jelenlétet). Hátrány azonban a müholdakhoz képest a légköri repülés által jelentett jogszabályi korlátok léte, a nagy repülési magasságú RPASokhoz képest pedig az alacsonyabb sebesség.

A fentiek alapján szükséges annak további vizsgálata, hogy a pszeudomüholdak hogyan illeszthetők be a katonai múveletek támogatási portfóliójába, és milyen módon kell a műveleteiket megtervezni és összehangolni a hasonló, jelen cikkben is tárgyalt rendszerekkel.

A publikáció az Innovációs és Technológiai Minisztérium Kooperatív Doktori Program Doktori Hallgatói Ösztöndíj Programjának a Nemzeti Kutatási, Fejlesztési és Innovációs Alapból finanszírozott szakmai támogatásával készült.

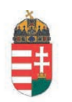

NEMZETI KUTATÁSI, FEILESZTÉSI ÉS INNOVÁCIÓS HIVATAL INNOVÁCIÓS ÉS TECHNOLÓGIAI MINISZTÉRIUM

\section{HivATKOZOTT IRODALOM}

[1] AGI Systems Tool Kit szoftver, https://www.agi.com/ products/stk (Letöltve: 2021.5.25.);

[2] Forrás: https://storage.googleapis.com/afs-prod/med ia/12246c1c0a9e4cdc909daf39c817ce3f/1000.jpeg (Letöltve 2021.4.16);
[3] Alejandro Aragón-Zavala, José Luis Cuevas-Ruíz, José Antonio Delgado-Penin, High Altitude Platforms for Wireless Communications, Wiley, 2008.;

[4] Airbus, „Zephyr S set to break aircraft world endurance record" 2018.7.25. https://www.airbus. com/newsroom/press-releases/en/2018/07/ Zephyr-S-set-to-break-aircraft-world-endurancerecord.html (Letöltve: 2021.4.20.);

[5] Thales, „Thales Alenia Space and Thales sign concept study contract with French defense procurement agency for a Stratobus type platform" 2020.1.8. https://www.thalesgroup.com/en/ worldwide/space/press-release/thales-alenia-spaceand-thales-sign-concept-study-contract-french (Letöltve 2021.4.16);

[6] ESDPA.org, „Airbus tests stratospheric 4G/5G defence communications" 2018.9.25. https://www. esdpa.org/airbus-successfully-tests-stratospheric4g-5g-defence-communications/ (Letöltve 2021.4.16);

[7] Manfred „Dutch” von Ehrenfried, Stratospheric Balloons: Science and Commerce at the Edge of Space. Springer International Publishing, 2021. doi:10.1007/978-3-030-68130-2;

[8] Army Recognition, „Chinese Soar Dragon HALE UAV Unmanned Aerial Vehicle used to spy US Navy USS Antietam" 2019.8.4. https://www.armyrecognition. com/august_2019_global_defense_security_army_ news_industry/chinese_soar_dragon_hale_uav_ unmanned_aerial_vehicle_used_to_spy_us_navy_ uss antietam.html (Letöltve: 2021.4.14.);

[9] Airforce Technology, „Bayraktar Akinci Unmanned Combat Aerial Vehicle (UCAV)" https://www.airforce-technology.com/projects/ bayraktar-akinci-unmanned-combat-aerial-vehicleucav/ (Letöltve: 2021.4.16.);

[10] Airforce Technology, „RQ-4A/B Global Hawk HALE Reconnaissance UAV" https://www.airforce-technology.com/projects/ rq4-global-hawk-uav/ (Letöltve: 2021.4.16);

[11] Enis A. A. Shatri, High Altitude Platforms Opportunities and Legal Challenges, Lambert Academic Publishing, 2019.

\section{JegYzeteK}

1 A greenwichi középidőt (GMT) 1961-ben felváltó egyezményes koordinált világidő (UTC) az a hivatkozási időzóna, amelyhez a Föld többi időzónáját viszonyítjuk. A bolygó 50 különböző

laboratóriumában mért nemzetközi atomidőből származik, de a Föld lassuló és nem egyenletes forgása miatt az eltérés kiküszöbölése érdekében egy-másfél évente egy szökőmásodpercet adnak hozzá (A szerk.).

2 A szimuláció az Analytical Graphics Systems ToolKit szoftverrel készült.

3 A Van Allen sugárzási övezetnek nevezik a Földet körülvevő, elektromosan töltött részecskéket tartalmazó dupla gyürüket, amelyeket a napszél hoz létre. A belső öv 10-50 MeV energiájú protonokból áll, 2000-5000 km-ig terjed a Föld felett. A 6000$10000 \mathrm{~km}$ vastag külső öv, legsürübb része $15000-20000 \mathrm{~km}$ magasságban található, főleg elektronokból áll. A két zóna nem válik el élesen egymástól. Az öveket 1958-ban az Explorer-1 és 3 amerikai műholdak Geiger-Müller-számlálóval történt mérései alapján fedezték fel. A műholdak műszereit az lowai Egyetem fizika tanszékének vezetője, James Van Allen (1917-2006) tervezte (a szerk.). 